\title{
Etik Liderlik ve Çalışanların Yenilikçi Davranışı: Lider-Üye Etkileşimi ve Duygusal Zekânın Düzenleyici Aracılık Modeli
}

\author{
Yavuz Selim DÜGER \\ Kütahya Dumlupınar Üniversitesi \\ yselim.duger@dpu.edu.tr \\ ORCID ID: 0000-0003-3523-9671
}

\begin{tabular}{lrr}
\hline Araştırma Makalesi & DOI: $10.31592 /$ aeusbed.702443 \\
\hline Geliş Tarihi: 12.03 .2020 & Revize Tarihi: 23.09 .2020 & Kabul Tarihi: 01.10 .2020
\end{tabular}

\section{Atıf Bilgisi}

Düger, Y. S. (2020). Etik liderlik ve çalışanların yenilikçi davranışı: Lider-üye etkileşimi ve duygusal zekânın düzenleyici aracılık modeli. Ahi Evran Üniversitesi Sosyal Bilimler Enstitüsü Dergisi, 6(3), 706-725.

\section{ÖZ}

Değişimin hızlı olduğu günümüz iş dünyasında, yeniliği arayan ve değişimi takip eden çalışanlar örgütler için son derece büyük öneme sahiptir. Çalışanların yenilikçi davranış sergilemeleri noktasında ise liderlerin örgüt içerisinde sergilediği tutum ve davranışlar belirleyici olmaktadır. $\mathrm{Bu}$ araştırmada etik liderlik, lider-üye etkileşimi ve duygusal zekânın çalışanların yenilikçi davranışlar sergilemesinde etkisi olup olmadığının belirlenmesi amaçlanmaktadır. Etik liderlik ile yenilikçi davranış arasındaki ilişkide lider-üye etkileşiminin aracılık rolünü ve bu aracılık rolünde duygusal zekânın düzenleyici (moderatör) etkisini ortaya koymak hedeflenmiştir. $\mathrm{Bu}$ araştırmada nihai olarak, etik liderliğin çalışanların yenilikçi davranış üzerindeki etkisi lider-üye etkileşimi ve duygusal zekânın düzenleyici aracılık modeli çerçevesinde incelenmektedir. Bu doğrultuda Kütahya'da faaliyet gösteren çini ve porselen işletmelerinde çalışan 239 kişiye ulaşılarak anket aracılı̆̆ $\breve{1}_{1}$ ile veriler toplanmıştır. Araştırma sonucuna göre; etik liderliğin, lider-üye etkileşiminin ve duygusal zekânın çalışanların yenilikçi davranışlarına olumlu etkileri vardır. Etik liderlik ile yenilikçi davranış arasında lider-üye etkileşiminin kısmi aracılık etkisinin olduğu sonucuna ulaşılmıştır. Lider-üye etkileşimi ile yenilikçi davranış arasındaki ilişkide, duygusal zekânın düzenleyici rolünün de olduğu belirlenmiştir. Ayrıca, düzenleyici aracılık modeli anlamlı olmasına rağmen, negatif bir değere sahip olduğu için desteklenmemiştir. Anahtar Kelimeler: Etik liderlik, lider-üye etkileşimi, duygusal zekâ, yenilikçi davranış, düzenleyici aracılık modeli.

\section{Ethical Leadership and Innovative Behavior of Employees: A Moderated Mediation Model of Leader Member Exchange and Emotional Intelligence}

\begin{abstract}
In today's business world, where change is fast, employees seeking innovation and following change are extremely important for organizations. Leaders' attitudes and behaviors within the organization are determinants in terms of employee innovative behavior. In this study, it is aimed to determine whether ethical leadership, leader-member exchange, and emotional intelligence have an effect on employees' innovative behaviors. In the relationship between ethical leadership and innovative behavior, it was purposed to reveal the mediating role of leader-member exchange and the moderator effect of emotional intelligence in this mediating role. In this study, it is ultimately aimed to analyze the effect of ethical leadership on employees' innovative behavior within the framework of the moderated mediation model of the leader-member exchange and emotional intelligence. For this purpose, 239 employees were reached who working in the tile and porcelain manufacturer located in Kütahya and data were collected through a questionnaire. According to the research result; It has been concluded that ethical leadership, leader-member exchange, and emotional intelligence have a positive effect on the innovative behavior of employees, that there is a partial mediating effect of leader-member exchange between ethical leadership and innovative behavior, and emotional intelligence has a moderator role in the relationship between leader-member exchange and innovative behavior. In addition, although the moderated mediation model is significant, it is not supported because it has a negative value.
\end{abstract}

Keywords: Ethical leadership, leader-member exchange, emotional intelligence, innovative behavior, moderated mediation model.

\section{Giriş}

Dünyada son 20 yılda meydana gelen değişim, önceki dönemlere göre çok daha hızlı gerçekleşmiştir. Değişim, teknolojinin yanı sıra sistemler, metotlar, ürünler, hizmetler, kültür, tüketici istek ve beklentileri vb. birçok alanda kendini göstermiştir. Değişimin bu kadar hızlı yaşandığı günümüzde, işletmelerin uzun vadede varlığını devam ettirebilmeleri değişimin içinde yer almalarına 
ve değişimin öncüleri olmalarına bağlıyken, işletmelerin değişime cevap verebilme kapasiteleri ise, sahip olduğu nitelikli ve örgütsel sadakati yüksek çalışanlara sahip olmalarına bağlıdır. Bu bağlamda değişimi arayan, takip eden, isteyen ve bu motivasyona sahip olan çalışanlar işletmeler için son derece büyük öneme sahiptir. Ayrıca, değişimin öncüsü olmak isteyen işletmeler sadece bir konuda uzmanlaşan değil, uzmanlaştığı konuda değişimi arayan 'değişim ajanlarına' ihtiyaç duymaktadırlar.

Değişim noktasında çalışanların yenilikçi davranışları, ürünler, uygulamalar, hizmetler veya prosedürler hakkında yeni ve faydalı fikirlerin üretilmesi, tanıtılması ve uygulanması olarak karşımıza çıkmaktadır (Zhou, 2003). Çalışanların iş ortamında, ekstra rol davranışı olarak, yenilikçi davranışlar sergilemesini etkileyen faktörleri belirlemeye yönelik literatürde birçok araştırma yapılmıştır. İşletmelerdeki yönetim anlayışının çalışanların yenilikçi davranışlar sergilemesinde önemli bir etkiye sahip olduğu düşüncesinye yapılan literatür incelemesinde, araştırmacılar tarafindan liderlik stillerini konu alan çalışmalara sınırlıda olsa rastlanmaktadır. Etik liderlik anlayışının çalışanların yenilikçi davranışlarına etkisini konu alan araştırmalar (Kalyar, Usta ve Shafique, 2019; Özsungur, 2019; Tu ve Lu, 2013; Yidong ve Xinxin, 2013; Zehra ve Waheed, 2017) ayrıca, dönüşümcü liderlik (Eisenbei $\beta$ ve Boerner, 2013), güçlendirici liderlik (Zhang ve Bartol, 2010), demokratik, otoriter ve serbestçi liderlik (Lin ve $\mathrm{Wu}, 2018$ ) yaklaşımlarının çalışanların yenilikçi davranışlarına etkisini konu alan araştırmalar da bulunmaktadır.

Yöneticiler/liderler çalışanlara pozitif enerji vererek, psikolojik olarak onları güçlendirerek ve çalışanlarla kaliteli ilişkiler geliştirerek onları yenilikçi davranışlar sergilemesi noktasında teşvik edici olabilmektedir (Ma, Cheng, Ribbens ve Zhou, 2013). Ayrıca, etkili bir liderlik tarzı çalışanların yenilikçi davranışlar sergilemesi için katalizör görevi görebilmektedir (Atitumpong ve Badir, 2018). $\mathrm{Bu}$ bağlamda, etik liderliğin örgüt içerisinde ahlak, adalet, özerklik ve insan odaklılık gibi değerlere hitap etmesinden dolayı, özellikle moral ve motivasyon açısından çalışanların yenilikçi davranışları üzerinde olumlu etkileri olduğu bilinmektedir (Ma vd., 2013). Ayrıca, etik liderliğin çalışanların yenilikçi davranışına olan etkisinin yanı sıra, çalışanların memnuniyet düzeyini olumlu yönde etkilediği, örgütsel bağlılık düzeylerini artması noktasında etkisinin olduğunu, iş ahlak değerlerinin oluşturması ve örgütsel vatandaşlık davranışlarının geliştirmesine yardımcı olduğu da bilinmektedir (Dhar, 2016).

Bir diğer liderlik yaklaşımı olan lider-üye etkileşimi, çalışanların her biri ile kişiselleştirilmiş ilişkilerin kurulduğu, özellikle güven ve performans bağlamında çalışanlarla etkileşimin geliştirildiği bir yaklaşımdır (Baş, Keskin ve Mert, 2010). Lider-üye etkileşiminin sosyal değişim teorisi çerçevesinde açıklanması, çalışanların yenilikçi davranışlarına olan etkisini anlama açısından önemlidir. Sosyal değişim teorisi kişilerin kazanım elde etmek için içsel motivasyonla gönüllü olarak olumlu davranışlar sergilemesi olarak açıklanabilir (Aydın, 2017). Lider-üye etkileşimi sonucunda liderlerin çalışanlarına sunduğu maddi ya da psikolojik tatmine dayalı kazanımlar çalışanların örgüt içerisinde ekstra çaba sarf etmesine yol açmaktadır (Düger, 2020). Bu ekstra rol davranış1 örgütlerde çalışanların yenilikçi davranış sergilemesi olarak kendini göstermektedir. Literatürde yapılan bazı çalışmalar (Atitumpong ve Badir, 2018; Gu, Tang ve Jiang, 2015; Saeed, Afsar, Cheema ve Javed, 2019) bunu kanitlamaktadir.

Çalışanların yenilikçi davanışlar sergilemesi noktasında, liderliğin etkisi olduğu gibi çalışanlarında sahip olduğu bazı özelliklerin etkisi olabilmektedir. Sosyal zekânın bir parçası olan duygusal zekâ, kişilerin kendi duygularını daha iyi tanımlayabilmelerine ve yönetebilmelerine, başkalarının duygularını anlayabilme ve iyi bir şekilde karşılık verebilmeleri olarak tanımaktadır (Ordun ve Acar, 2014). Duygusal zekâ, kişiyi psikolojik açıdan ele aldığından dolayı iş ortamında sergileyeceği davranışları açıklamada yardımcı olabilmektedir. Bununla birlikte, çalışanların sahip olduğu duygusal zekâ, örgüt içerisinde iyi bir performans sergilemesine neden olabilmektedir (Shojaei ve Siuki, 2014). Duygusal olarak zeki çalışanların işe daha fazla motive oldukları ve daha üretken davranışlar sergilediklerini, bununla birlikte, duygusal zekânın çalışanların yenilikçi davranışlar sergilemesi noktasında kilit rol oynadığını yapılan bazı çalışmalarda ortaya koymaktadır (Al-Omari, 2017; Dinçer ve Orhan, 2012). 
$\mathrm{Bu}$ çalışmanın amacı ilk olarak etik liderliğin çalışanların yenilikçi davranışlarına olan etkisini ortaya çıkarmaktır. İkinci olarak, etik liderlik ile çalışanların yenilikçi davranışları arasında lider-üye etkileşiminin aracılık rolünü keşfetmektir. Üçüncü olarak, lider-üye etkileşiminin çalışanların yenilikçi davranışlarına olan etkide duygusal zekânın bu etkiye olan katkısını ortaya koymaktır. Son olarak, geliştirilen düzenleyici aracılık modeli çerçevesinde bütüncül bakış açısıyla etik liderliğin çalışanların yenilikçi davranışına olan etkisini değerlendirmektir.

\section{Etik Liderlik}

Brown, Trevino ve Harrison (2005) etik liderliği "kişisel eylemler ve kişiler arası ilişkiler yoluyla normatif olarak uygun davranışın gösterilmesi ve bu tür davranışların iki yönlü iletişim, güçlendirme ve karar verme yoluyla takipçilerin teşvik edilmesi" olarak tanımlamaktadır. Bu tanıma göre etik lider, belirli özellikler taşıması ve bunlara uygun davranışlar sergilemesi gereken bir yöneticidir. Etik liderler, çalışanların refahını önemseyen fedakâr, dürüst, güvenilir ve ilkeli karar vericilerdir. Etik liderlerin, etik kodları iletme, çalışanları etik eylemlerden sorumlu tutma ve çalışanları dönüştürme görevleri vardır (Hassan, Mahsud, Yukl ve Prussia, 2013). Etik lider örgüt içerisinde ve dışında etik davranışlar sergileyen ve bu davranışları diğer çalışanların uyması için teşvik eden önemli bir faktördür. Ayrıca etik liderlik, diğer liderlik tarzlarından farklı olarak, daha çok bireyin ahlaki ve etik davranışına odaklanır ve bu davranışların çalışanlar arasında yaygınlaşmasını amaçlamaktadır (Kalyar vd., 2019).

Etik liderler, çalışanların fikirlerini özgürce ifade etmesi ve çekincelerini dile getirmesi için onlara firsat sunmaktadırlar. Ayrıca, çalışanların karar alma sürecine katılmasını ve belirli bir özerkliğe sahip olmasını sağlamaktadırlar (Brown vd., 2005: 120; De Hoogh ve Den Hartog, 2008: 298). Etik liderler sahip olduğu gücü dürüstlük çerçevesinde çalışanlarıyla paylaşarak, çalışanların kendi işleri üzerinde kontrol sağlamalarını ve daha az bağımlı hareket etmelerini teşvik etmektedirler (Resick, Hanges, Dickson ve Mitchelson, 2006). Böylelikle etik liderler çalışanları güçlendirerek yapılan işin çalışanlar açısından daha anlamlı hale gelmesini sağlamaktadırlar. Buradan hareketle De Hoogh ve Den Hartog (2008) etik liderliğin birleşenlerini; ahlak, adalet, etik rol belirleme ve güç paylaşımı olarak sıralamaktadır.

Etik liderliği planlı davranış teorisi çerçevesinde ele alan Rahaman, Stouten ve Guo (2019), etik davranışlar gerçekleştirmek isteyen liderlerin etik tutumlara sahip olması durumunda, büyük ihtimalle örgüt içerisinde de etik davranış sergileme eğiliminde olacağını belirtmektedir. Etik davranışların öncüsü olan etik tutumlar ise doğruyu savunmayı, çalışanlara ve diğer paydaşlara karşı güvenilir ve saygılı olmayı kapsamaktadır. Brown vd., (2005) ise etik liderliği sosyal öğrenme teorisi çerçevesinde ele almaktadır. Sosyal öğrenme teorisine göre lider sergilediği davranışlar ile çalışanlara rol model olmakta ve çalışanların etik davranışlar sergilemesi noktasında ilham kaynağı olmaktadırlar. Cropanzano ve Mitchell de (2005) etik liderliği sosyal değişim teori çerçevesinde ele almaktadır. Sosyal değişim teorisine göre çalışanların ve liderlerin karşllıklılık ilkesi gereği hareket edeceklerini varsaymaktadır. Çalışanların olumlu örgütsel davranışlar sergilemesinin, liderin adil, güvenilir ve dürüst olmasına bağlı olduğunu ifade edilmektedir (Mayer vd., 2009). Bu özellikleriyle etik lider yapıcı liderlik olarak kabul edilirken, etik değerleri taşımayan liderlik ise yıkıcı liderlik olarak kabul edilmektedir (Biçer, 2020).

\section{Çalışanların Yenilikçi Davranışı}

Literatürde yenilikçilik kavramı süreç ve sonuç olmak üzere iki farklı anlayışta kavramsallaşmıştır. Yenilik ürün, hizmet veya metotlara yönelik yeni fikirlerin örgütsel performansa katkı sağlaması noktasında gerçekleşen süreçler bütünü şeklinde tanımlanmaktadır. Diğer taraftan yenilik, bir alana özgü yeni ve yararlı fikirlerin sonucunu ifade etmektedir. Yenilik aynı zamanda mevcut ürün, hizmet ya da metotlar ile yeni fikirlerin kombinasyonu sonucunda oluşmaktadır (Kalyar vd., 2019). Çalışanların yenilikçi davranışı ise fikirlerin geliştirilmesinin ötesinde yeni fikirler için çalışanların teşvik edilmesi ve yeni fikirlerin uygulamasını da içeren bir süreçtir (Zehra ve Waheed, 2017). Farr ve Ford (1990) göre çalışanların yenilikçi davranış1, "kişinin istekli olarak iş rolüne uygun 
yeni ve faydall fikirlerin, süreçlerin, ürünlerin veya prosedürlerin geliştirilmesi için girişimde bulunulmasıdır". Scott ve Bruce (1994) çalışanların yenilikçi davranışlarını fikirlerin üretilmesi, fikirlerin geliştirilmesi ve fikirlerin gerçekleştirilmesi şeklinde üç temel süreçten oluştuğunu ileri sürmüştür. Fikirlerin üretilmesi aşamasında, çalışanlar bir sorunu fark eder ve alış1lmış yeni çözümler ve fikirler üretirler. Fikirlerin geliştirilmesi aşamasında, çalışanlar kendi çözümlerini ve fikirlerini geliştirirler. Fikirlerin gerçekleştirilmesi aşamasında, çalışanlar bir inovasyon modeli oluşturur ve bu modeli organizasyonlarına uygulayarak fikri gerçekleştirirler.

Yenilikçi davranışlar bireyin kişisel özelliklerden (risk alma, yenilik yapma eğilimi, kişisel ilgi, uzmanlık yönelimi) ve bilişsel özelliklerden (problem çözme stili, sistematik yaklaşımlar) ortaya çıkmaktadır (Bal Taştan ve Davoudi, 2015). Çalışanların yenilikçi davranışı, mevcut çalışma yöntemlerini iyileştirmeyi ve sorunları düşünmeyi, insanların karşılanmamış ihtiyaçlarını belirlemeyi, yeni trendleri ve değişimleri takip etmeyi, yeni çözümler önermeyi, bilgi paylaşmayı ve sorunları yeni yollarla ele almayı kapsamaktadır (De Jong ve Den Hartog, 2007; Yidong ve Xinxin, 2013). Yenilikçi çalışan davranışları, yaratıcı davranışları kapsamakla birlikte farklılık da göstermektedir. Yenilikçi çalışma davranışları, fikir üretmenin yanı sıra fikir geliştirme ve fikirleri uygulamayı kapsadığından dolayı farklılık göstermektedir. Ayrıca, çalışanların yenilikçi davranışı, yeni teknolojilerin keşfedilmesi, hedeflere ulaşılabilmesi için yeni yolların bulunması, yeni yöntemlerin uygulanması ve yeni fikirleri geliştirilmesi için kaynakları araştırmayı içermektedir (Zahra, Ahmad ve Waheed, 2017). Sonuç olarak işletmelerin rekabet avantajı elde edebilmeleri ve iş performansını iyileştirebilmeleri, sahip oldukları yenilikçi davranışlar sergileyen çalışanlara bağlıdır.

\section{Lider-Üye Etkileşimi}

'Dikey ikili ilişki teorisi' olarak adlandırılan, lider-üye etkileşim teorisine yönelik ilk çalışmalar Dansereau, Graen ve Haga (1975) tarafından yapılmıştır. Lider-üye etkileşimi, lider ile çalışanlar arasında meydana gelen değişim sürecini açıklayan bir yaklaşımdır. Graen ve Uhl-Bien'e (1995) göre bu yaklaşım "taraflar arasında güven, saygı ve karşıllkl yükümlülüklere odaklanan ilişki temelli bir yaklaşımdır". Taraflar arasında ilişkinin seviyesi ve kapsamı farklılık gösterebilmektedir. Yüksek ilişkisel kalitenin meydana geldiği durumda liderler, çalışanların işlere yönelik ekstra gayret göstermesini bekler ve çalışanlar da liderlerden güven, saygı, ödüllendirme vb. beklemektedir. Bununla birlikte, taraflar arasında ilişkisinin kalitesinin düşük olduğu durumlarda, çalışanlar sadece tanımlı iş sorumluluklarını yerine getirmeyi tercih ederler, ekstra görev ve sorumluluk üstlenmek istemezler, buna karşılık liderler bu tarz çalışanlarını maddi ve manevi olarak desteklemezler (Graen ve Uhl-Bien, 1995). Bu nedenle, lider-üye etkileşim kalitesi, ilişkinin niteliğgine bağlı olarak kişiden kişiye değişiklik göstererek düşük ya da yüksek seviyede gerçekleşebilir (Yu, Matta ve Cornfield, 2017).

Lider-üye etkileşim teorisine göre taraflar arasındaki ilişki kalitesi grup içi ve grup dışı olmak üzere iki kısımda incelenmektedir. Lider-üye etkileşim kalitesinin yüksek olduğu grup içinde, taraflar arasında yüksek düzeyde güven, saygı ve yükümlülükler oluşmaktadır. Bunun sonucunda, çalışanlar beklenenden daha fazla performans göstermekte ve ekstra rol davranışı sergilemektedirler. Lider-üye etkileşim kalitesinin düşük olduğu grup dişında ise taraflar arasında düşük düzeyde güven, saygı ve yükümlülükler oluşmaktadır. Çalışanların sadece iş tanımı ve görevlerini yerine getirmesi beklenmekte, liderin ve çalışanların karş11ıklı beklentileri düşük seviyede gerçekleşmektedir (Graen ve Uhl-Bien, 1995; Liden, Sparrowe ve Wayne, 1997).

\section{Duygusal Zekâ}

Duygusal zekâ literatürde çeşitli tanımlarla açıklanmasına karşın genel olarak birbirine yakın ifadeler kullanılmaktadır. Bu kavramı ilk defa ortaya atan Salovey ve Mayer (1990) duygusal zekâyı "kişinin ve başkalarının duygularını gözlemlemek, onları tanımak ve bu bilgiyi kişinin düşüncelerini veya eylemlerini yönlendirmek için kullanılan bir tür yetenek" olarak tanımlamıştır. Bir diğer tanımda Goleman (2006) duygusal zekayı "kişinin kendi duygularını anlaması, başkalarını anlamak için empati kurması ve her durumda kişiye katkı sağlayacak bir özellik" olarak tanımlamıştır. Bar-On 
(2006) ise duygusal zekâyı "başkalarlyla etkileşime geçmek ve onları anlamak, çevreden gelen talepleri karşılamak ve bunlarla başa çıkabilmek" olarak tanımlamıştır. Brackett, Mayer ve Warner, (2004), duygusal zekânın, kişilerin duygularıyla muhakeme yapma kapasitesini ve duygularını kullanarak muhakemesini geliştirme kapasitesini yansıttığını ileri sürmektedirler.

İşyerinde duygusal zekânın kullanımını inceleyen Jordan, Ashkanasy, Hartel ve Hooper (2002), duygusal zekâyı, zeki çalışanların duygusal olarak sergilediği pratik yetenekler şeklinde ifade etmektedir. Ayrıca, etkili çalışanların, özellikle kendinin ve çalışma arkadaşlarının duygularının farkında olmaları kendi duygularını ve başkalarının duygularını yönetebilmeleri gerektiğini savunmatadır. Jordan ve Lawrence (2009), Mayer ve Salovey'den (1997) esinlenerek duygusal zekây1 dört boyutta incelemiştir, (1) kendi duygularının farkında olmak, (2) kendi duygularının yönetimi, (3) başkalarının duygularının farkında olmak ve (4) başkalarının duygularının yönetimidir. Bazı araştırmacılar duygusal zekâyı öğrenilebilir ve geliştirilebilir bir çeşit yetenek olduğunu ileri sürmektedirler. Buradan hareketle, duygusal zekâ psikolojik açıdan kişinin özünü yansıttığından yönetim alanında kullanılabilecek yaygın bir yaklaşım haline gelmiştir (Al-Omari, 2017).

Duygusal zekâ yeteneğinin, büyük ölçüde kişilerarası ilişkileri yönetmekle ilgili olduğunu ileri süren Mayer ve Salovey (1997), bu yeteneği bireylerin kendilerinin ve diğer çalışanların duygularını tanımasına, anlamasına ve yönetmesine olanak sağladığından dolayı işyerinde daha iyi ilişkilerin geliştirilmesine ve performansın iyileştirilmesine katkıda bulunduğunu savunmaktadır. Chopra ve Kanji (2010) duygusal zekânın insan potansiyelinin gelişimi, örgüt içerisinde ilişki yönetimi, takım çalışması, etkili liderlik, iş performansı, örgütsel gelişim, stresi azaltılması, yaratıcılık ve yenilik üzerinde büyük öneme sahip olduğunu iddia etmektedir.

\section{Değişkenler Arasında İlişki ve Hipotezler}

Etik lider, dürüst ve güvenilir olan, adil kararlar veren, çalışanları daha fazla önemseyen bir lider olarak görünmektedir. Çalışanlar kendileriyle ilgilenen, karşılıklı güven ve saygıyı tesis eden bir liderlik davranışıyla karşılaştıklarında, lider ile çalışan arasında ilişkinin kalitesinin artacağı düşünülmektedir (Graen ve Uhl-Bien, 1995; Hassan vd., 2013). Ayrıca etik liderler, örgüt içerisinde destekleyici ve motive edici yaklaşımlar sergileyerek, çalışanların çıkarlarını koruyucu hareket etmektedirler. Böylelikle, çalışanların liderlerine olan bağlılığı artmaktadır. Karş1lıklılık ilkesi gereği çalışanların lidere yönelik geliştirdikleri yüksek inanç, aidiyet duygusu ve sadakat yüksek kalitede bir lider-üye etkileşiminin meydana gelmesine yol açmaktadır. Sonuç olarak, etik liderler çalışanlar ile güçlü sosyal değişim ilişkileri geliştirebilir, bu da yüksek kalitede bir lider-üye etkileşiminin gelişmesiyle sonuçlanmaktadır (Dhar, 2016). Bu bağlamda etik liderliğin lider-üye etkileşim kalitesinin artmasına neden olacağı düşünüldüğünden, aşağıdaki hipotez önerilmektedir:

$\mathbf{H}_{1}$ : Etik liderliğin lider-üye etkileşimi üzerinde pozitif yönlü anlamlı bir etkisi vardır.

Lider-üye etkileşim düzeyinin yüksek kalitede gerçekleşmesi durumunda, çalışanların borçluluk hissi ile hareket ederek örgüte daha fazla katkı sağlaması noktasında yenilikçi davranışlar gibi ekstra rol davranışları sergilemesi beklenmektedir (Liao, Hu, Chung ve Chen, 2017). Ayrıca güvene dayalı karşılıklı yarar sağlama ilkesinden hareketle, yüksek kalitede gerçekleşen lider-üye etkileşimi, çalışanları yüksek iş performansı ile yeni iş fikirleri geliştirmeye yönlendirmektedir (Raghuram, Gajendran, Liu ve Somaya, 2017). Yüksek kalitede gerçekleşen lider-üye etkileşimi ile liderlerin çalışanlarıyla birlikte daha fazla vakit geçirmesi ve çalışanlarına fikirlerini söylemesi için daha fazla firsat sunması, çalışanların yenilikçi davranışlar sergilemesi noktasında teşvik edici olabilmektedir. Bununla birlikte, çalışanların liderlerinden işle ilgili daha fazla bilgi ve daha fazla duygusal destek almaları yenilikçi davranışlar sergilemeleri için onları teşvik edebilmektedir (Schermuly, Meyer ve Dämmer, 2013). Bu bağlamda lider-üye etkileşiminin çalışanların yenilikçi davranışlarının artmasına neden olacağı düşünüldüğünden aşağıdaki hipotez önerilmektedir:

$\mathbf{H}_{2}$ : Lider-üye etkileşiminin yenilikçi davranış üzerinde pozitif yönlü anlamlı bir etkisi vardır. 
Liderler tarafından etik davranışların sergilenmesi, nihayetinde çalışanların daha iyi performans göstermesine, motive olmasına, yaratıcı ve yenilikçi davranışlar sergilemesine yol açmaktadır (Ma vd., 2013). Liderlerin etik davranışlarına, sosyal değişim teorisi çerçevesinde, çalışanlar daha fazla çaba göstererek karşılık vermekte ve yenilikçi çalışma davranışları sergilemektedirler (Brown vd., 2005). Adil kararlar veren, dürüst ve güvenilir olan etik lider, çalışanların örgütsel adalet ve bağlılık duygusunu arttırmakta, böylelikle yenilikçi fikirlerin ortaya çıkmasına zemin oluşturmaktadır (Brown vd., 2005; De Hoogh ve Den Hartog, 2008). Ayrıca, etik liderler çalışanlarıyla güçlü ilişkiler geliştirmekte, güvene dayalı açık ve şeffaf iletişim kurmakta, böylelikle görüş ve fikirlerin özgürce ifade edilebileceği bir ortam oluşturmaktadırlar (Duan vd., 2018). Bu bağlamda etik liderliğin çalışanların yenilikçi davranışlarının artmasına neden olacağı düşünüldügünden, aşağıdaki hipotez önerilmektedir:

$\mathbf{H}_{3}$ : Etik liderliğin yenilikçi davranış üzerinde pozitif yönlü anlamlı bir etkisi vardır.

Etik liderler sergilediği karakteristik davranışlar ile çalışanları arasında yüksek kalitede ilişkiler geliştirmektedirler, bu durum yenilikçilik noktasında çalışanların yüksek performans göstermesini sağlamaktadır (Liao, Chen ve Hu, 2018). Örgüt içerisinde liderlerin tüm çalışanlara eşit ve adil davranıldığını hisseden çalışanlar, liderle güçlü ilişkiler geliştirmeyi tasarlamakta ve bu durum lider-üye etkileşim kalitesini de yüksek olmasını sağlamaktadır. Yüksek kalitede lider-üye etkileşimi gerçekleştiğinde, çalışanların organizasyonlarına değer sağlama noktasında yenilikçi davranışlar sergilemesi beklenmektedir (Kalyar vd., 2019). Bu bağlamda etik liderliğin çalışanların yenilikçi davranış sergilemesi noktasındaki etkisi lider-üye etkileşimi kalitesi üzerinden gerçekleşeceği düşünüldüğünden, aşağıdaki hipotez önerilmektedir:

H4: Etik liderlik ve yenilikçi davranış arasındaki ilişkide lider-üye etkileşiminin aracı rolü vardir.

Duygusal zekânın çalışanların performansına olumlu bir etkisi olduğu daha önce yapılan çalışmalarda kanıtlanmıştır (Dinçer ve Orhan, 2012). Çalışanların sahip olduğu yüksek duygusal zekânın iş performansına olumlu etkisinin yanı sıra, çalışanların ekstra rol davranışları gösterme eğilimlerini de arttırmaktadır (Al-Omari, 2017). Duygusal olarak zeki çalışanlar iş arkadaşları ile daha iyi bir ilişki kurma eğilimi göstermekte ve iş tatmin düzeyleri daha yüksek olmaktadır (Lopes, Salovey ve Straus, 2003; Wong ve Law, 2002). Ayrıca, Carmeli (2003), duygusal zekânın çalışanların iş tatminine olumlu etkisi olmasının yanı sıra, çalışanların duygusal bağlılığı ve özgeci davranışlarına da olumlu etkileri olduğunu belirtmiştir. $\mathrm{Bu}$ durum, örgütte çalışanlar arasında daha fazla bilgi paylaşımına, dolayısıyla sorunların çözümüne yönelik ya da iş süreçlerinin geliştirilmesine yönelik yeni fikirlerin üretilmesine yol açmaktadır. Diğer taraftan, duygusal zekâsı yüksek olan çalışanlar, olumlu davranışlar sergileme eğilimindedir, bu durum çalışanlar arasında iyimserlik anlayışının yayılmasına ve yenilikçi fikirleri benimsemelerini kolaylaştırmaktadır. Böylelikle çalışanların geniş bir düşünce ve esneklik gösterme olasılığı ortaya çıkmaktadır (Al-Omari, 2017). Bu bağlamda duygusal zekânın çalışanların yenilikçi davranışlarının artmasına neden olacağı düşünüldüğünden, aşağıdaki hipotez önerilmektedir:

H5: Duygusal zekânın yenilikçi davranış üzerinde pozitif yönlü anlamlı bir etkisi vardır.

Duygusal zekâ, çalışanların yöneticileriyle arasındaki duygusal bağlılığı güçlendiren ve liderüye etkileşiminin etkisini artıran bir unsurdur. Duygusal zekânın yüksek seviyede gerçekleşmesi, lider-üye etkileşim kalitesinin artmasına ve etki gücünün yükselmesine neden olurken, tam aksine duygusal zekânın düşük seviyede gerçekleşmesi lider-üye etkileşim kalitesini zayıflamasına ve etki gücünü de düşmesine yol açmaktadır (Qian, Wang, Han ve Song, 2017). Ayrıca, Jordan ve Troth (2011) duygusal zekânın, lider-üye etkileşiminin özü olan ilişki sorunlarını anlamada ve ele almada yararlı olacağından dolayı lider-üye etkileşiminin kalitesini doğrudan etkileyeceğini savunmaktadır. Liderin duygusal zekâsının yanı sıra, çalışanların da sahip olduğu duygusal zekânın lider-üye etkileşimini etkileyeceğini iddia etmektedir. Bu bağlamda, duygusal zekânın modele katılması sonucu, 
lider-üye etkileşimi ile çalışanların yenilikçi davranışı arasındaki ilişkinin gücü artacağı düşünüldüğünden, aşağıdaki hipotez önerilmektedir:

H6: Lider-üye etkileşimi ve yenilikçi davranış arasındaki ilişkide duygusal zekânın düzenleyici rolü vardır.

Etik liderliğin çalışanların yenilikçi davranışlarına etkisi olduğu gibi bu etkinin bir kısmı ya da tamamının lider-üye etkileșimi üzerinden gerçekleștiği öngörülmektedir. Özellikle yüksek kalitede gerçekleşen lider-üye etkileşiminin sonucunda sosyal değişim teorisi çerçevesinde çalışanlardan yüksek karşılık beklentisi oluşmaktadır. Liderlerin çalışanlarını maddi ya da maddi olmayan yollardan destekleyerek motive etmesi sonucunda borçluluk hissi ile daha fazla performans göstermeleri beklenilmektedir. Bunun sonucunda modele lider-üye etkileşiminin aracılık rolüyle dâhil olması etik liderliğin çalışanların yenilikçi davranışına olan etkisini lider-üye etkileşiminin seviyesine bağlı olarak değişeceği öngörülmüştür. Bununla birlikte bu aracı etkinin oluşumunda özellikle lider-üye etkileşiminin çalışanların yenilikçi davranışlarına olan etkide duygusal zekânın düzenleyici bir rolü olduğu öngörülmüştür. Çalışanların kendi duygularını anlaması, kontrol etmesi ve başkalarının duygularını anlayıp ona göre davranışlar sergilemesi ister istemez lider-üye etkileşimi ile çalışanların yenilikçi davranışları arasındaki ilişkinin gücünü etkileyeceği düşünülmektedir. Bu varsayımlardan hareketle, tüm değişkenleri aynı anda analize ekleyerek, aracı ve düzenleyici etkiyi birlikte ele almak için amprik olarak aşağıdaki hipotez önerilmektedir:

H7: Etik liderlik ve yenilikçi davranıș arasındaki ilișkide aracılık etmesi beklenen lider-üye etkileşiminin, yenilikçi davranışa olan etkisinde duygusal zekânın düzenleyici rolü vardır. Diğer bir ifadeyle, duygusal zekânın düzenleyici etkisiyle birlikte lider-üye etkileşiminin etik liderlik ve yenilikçi davranış arasındaki aracılık etkisi artmaktadır.

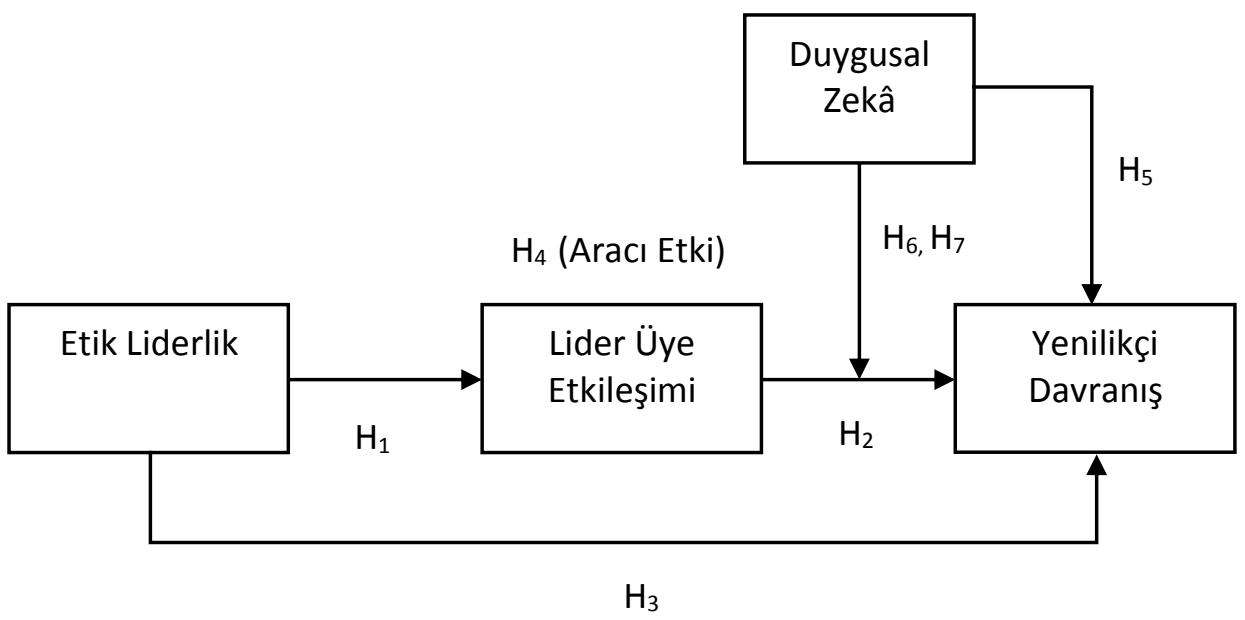

Şekil 1. Araştırma Modeli

\section{Yöntem}

Bu bölümde araştırmanın kapsamı ve yöntemi ile verilerin toplanması ve analizine ilişkin detaylı bilgiye yer verilmiştir.

\section{Araştırmanın Kapsamı ve Yöntemi}

Araştırma kapsamında, Kütahyada faaliyet gösteren 10 çini/porselen işletmesi ana kitle olarak seçilmiştir. Çini/porselen sektörü Türk kültürünü yurt dışında temsil eden bir sektör olduğundan ve yenilik, inovasyon ve tasarımın nispeten önemli olduğu düşünüldüğünden dolayı araştırmanın uygulanması için seçilmiştir. 2020 Mart ayında kolayda örneklem yöntemiyle toplamda 550 çalışanı 
bulunan ve izin alınan, 5 işletme çalışanlarına, 300 adet anket formu elden dağıtılmış ve değerlendirilebilir 239 (\% 80) adet anket formu dönüşü sağlanmıştır. Yanlızca resmi izin alınan işletmelerde çalışan personelden veri toplanabilmesi, örneklem sayısı açısından önemli bir sınırlılığı teşkil etmektedir. Anketler iki bölümden oluşmaktadır; birinci bölümde demografik değişkenleri belirlemeye yönelim 5 ifade, ikinci bölümde ise etik liderlik, yenilikçi davranış, lider-üye etkileşimi ve duygusal zekâ ölçek sorularından oluşan 44 ifade ve toplamda ise 49 ifade bulunmaktadır. Ayrıca bu çalışma Kütahya Dumlupınar Üniversitesi Rektörlügü̆, Sosyal ve Beşerî Bilimler Araştırma ve Yayın Etiği Kurulu tarafindan, 05.03.2020 tarihli 2020/02 kararıyla etik açıdan uygun bulunmuştur.

\section{Verilerin Toplanması ve Analizi}

Araştırmada etik liderlik, çalışanların yenilikçi davranışı, lider-üye etkileşimi ve duygusal zekâdan oluşan toplamda dört ölçek kullanılmaktadır. Ölçekler uluslararası literatürde geliştirilmiş ve Türkçeye uyarlaması yapılarak yerli literatüre araştırmacılar tarafindan kazandırılmıştır. Ölçeklerde kullanılan ifadeler 5'li likert tipi derecelendirme (1=Kesinlikle Katılmiyorum - 5=Kesinlikle Katılıyorum) aralığında kullanılmıştır. Etik liderliği ölçmek için Brown vd. (2005) tarafindan geliştirilen ve Tuna, Bircan ve Yeşiltaş (2012) tarafından Türkçe uyarlaması yapılan tek boyut ve 10 ifadeden oluşan ölçek kullanılmıştır. Çalışanların yenilikçi davranışını ölçmek için Scott ve Bruce (1994) tarafından geliştirilen ve Çalışkan, Akkoç ve Turunç (2019) tarafindan Türkçe uyarlaması yapılan tek boyutta 6 ifadeden oluşan ölçek kullanılmıştır. Lider-üye etkileşimini ölçmek için Liden ve Maslyn (1998) tarafından geliştirilen ve Baş vd. (2010) tarafından Türkçe uyarlaması yapılan dört alt boyut (duygusal etki, sadakat, katkı ve mesleki saygı) ve 12 ifadeden oluşan ölçek kullanılmıştır. Çalışanların duygusal zekâlarını ölçmek için Wong ve Law (2002) tarafından geliştirilen ve Hırlak, Taşlıyan, Fidan ve Gül (2017) tarafından Türkçe uyarlaması yapılan dört alt boyut (kendi duygularını değerlendirme, başkalarının duygularını değerlendirme, duyguların kullanılması ve duyguların düzenlenmesi) ve 16 ifadeden oluşan ölçek kullanılmıştır. Anketlerden elde edilen veriler AMOS, SPSS programı ve Process Macro (Hayes, 2013) eklentileri kullanılarak açıklayıcı ve doğrulayıcı faktör analizi, korelasyon analizi, doğrusal regresyon analizi ve düzenleyici (Model-1), aracı (Model4) ve düzenleyici aracılık analizleri (Model-14) çerçevesinde analizler gerçekleştirilmiştir.

\section{Bulgular}

\section{Demografik Bulgular}

Araştırmaya katılan 239 çalışanın \% 46'sı (110 kişi) kadın \% 54'ü (129 kişi) erkek, bunların \% 33,1'i (160 kişi) bekâr, \% 66,9'u (79 kişi) evlidir. Çalı̧̧anların \% 17,2'si (41 kişi) 18-25 yaş aralığında, \% 37,2'si (89 kişi) 26-37 yaş aralığında, \% 28,9'u (69 kişi) 38-45 yaş aralığında, \% 13'ü (31 kişi) 46-52 yaş aralığında ve \% 3,7'si de (9 kişi) 53 yaş ve üstünde bulunmaktadır. Katılımcıların \% 27,2'si (65 kişi) ilköğretim, \% 54,4'ü (130 kişi) lise, \% 4,6's1 (11 kişi) ön lisans, \% 10,9'u (26 kişi) lisans ve \% 2,9'u da (7 kişi) yüksek lisans mezunudur. Ayrıca katılımcıların \% 28'i (67 kişi) 1 yıldan az, \% 46,9'u (112 kişi) 1-5 yıl, \% 15,9'u (38 kişi) 6-10 yıl, \% 5,9'u (14 kişi) 11-20 y1l ve \% 3,3'ü (8 kişi) 20 yıl ve üzeri çalışma süresine sahiptir.

\section{Değişkenlere İlişkin Bulgular}

Araştırma modelinde kullanılan ölçeklerin faktör yapılarını tespit etmek, güvenilirlik ve geçerliliğini belirlemek için ilk olarak faktör analizi yapılmıştır. Ölçekler varimax rotasyon yöntemi kullanılarak ayrı ayrı temel birleşenler faktör analizine tabi tutulmuştur. Açıklayıcı faktör analizine ait bulgular Tablo 1'de verilmiştir. 
Tablo 1

Açıklayıcı Faktör Analizi Bulguları

\begin{tabular}{|c|c|c|c|c|c|}
\hline Ölçekler & Faktörler & $\begin{array}{l}\text { İfade } \\
\text { Say1s1 }\end{array}$ & $\begin{array}{l}\text { Faktör } \\
\text { Yükleri }\end{array}$ & $\begin{array}{l}\text { Cronbach } \\
\text { Alpha }\end{array}$ & Kaiser-Meyer-Olkin \\
\hline Etik Liderlik & Etik Liderlik (Tek Faktör) & 10 & $0,654-0,828$ & 0,913 & 0,900 \\
\hline \multirow{4}{*}{ Lider Üye Etkileşimi } & Sadakat & 3 & $0,743-0,822$ & \multirow{4}{*}{0,912} & \multirow{4}{*}{0,876} \\
\hline & Duygusal Etki & 3 & $0,754-0,899$ & & \\
\hline & Mesleki Sayg1 & 3 & $0,802-0,862$ & & \\
\hline & Katk1 & 3 & $0,728-0,840$ & & \\
\hline \multirow{4}{*}{ Duygusal Zekâ } & Kendi Duygularını Değerlendirme & 4 & $0,663-0,867$ & \multirow{4}{*}{0,899} & \multirow{4}{*}{0,870} \\
\hline & Başkalarının Duygularını Değerlendirme & 4 & $0,672-0,772$ & & \\
\hline & Duyguların Kullanılması & 4 & $0,636-0,872$ & & \\
\hline & Duyguların Düzenlenmesi & 4 & $0,552-0,799$ & & \\
\hline Yenilikçi Davranış & Yenilikçi Davranış (Tek Faktör) & 6 & $0,706-0,814$ & 0,854 & 0,815 \\
\hline
\end{tabular}

Faktör analizi sonucuna göre; etik liderliğe ilişkin ölçeğin faktör yüklerinin 0,654-0,828 aralığında olduğu, Cronbach Alpha değerinin 0,913 ve KMO değerinin 0,9 olduğu tespit edilmiştir. Lider üye etkileşimine ilişkin ölçeğin faktör yüklerinin genel olarak 0,728-0,899 aralığında olduğu, Cronbach Alpha değerinin 0,912 ve KMO değerinin 0,876 olduğu tespit edilmiştir. Duygusal zekaya ilişkin ölçeğin faktör yüklerinin genel olarak 0,552-0,872 aralığında olduğu, Cronbach Alpha değerinin 0,899 ve KMO değerinin 0,870 olduğu tespit edilmiştir. Çalışanların yenilikçi davranışına ilişkin ölçeğin faktör yüklerinin 0,706-0,814 aralığında olduğu, Cronbach Alpha değerinin 0,854 ve KMO değerinin 0,815 olduğu tespit edilmiştir. Bu sonuçlar tüm ölçeklerin faktör yapılarının düzgün dağıldığı ve yüksek derecede güvenilir olduğunu göstermektedir (Kalayc1, 2016).

Açıklayıcı faktör analizinden sonra etik liderlik ve yenilikçi davranış ölçekleri birinci düzey, lider-üye etkileşimi ve duygusal zekâ ölçekleri ikinci düzey doğrulayıcı faktör analizi yapılmıştır. Analiz sonucuna göre elde edilen uyun indeks değerleri Tablo 2'de verilmiştir.

Tablo 2

Doğrulayıcı Faktör Analizi Uyum İyiliği Değerleri

\begin{tabular}{lcccccc}
\hline Ölçekler & $\left(\mathrm{X}^{2} / \mathrm{sd}\right)$ & NFI & CFI & RMSEA & GFI & RMR \\
\hline Etik Liderlik & 2,393 & 0,957 & 0,974 & 0,076 & 0,949 & 0,026 \\
\hline Lider Üye Etkileşimi & 3,706 & 0,909 & 0,931 & 0,107 & 0,891 & 0,055 \\
\hline Duygusal Zekâ & 2,737 & 0,901 & 0,906 & 0,085 & 0,879 & 0,045 \\
\hline Yenilikçi Davranış & 4,298 & 0,960 & 0,968 & 0,118 & 0,964 & 0,026 \\
\hline
\end{tabular}

Doğrulayıcı faktör analizi sonucunda ölçeklere ilişkin uyum iyiliği değerleri iyi/kabul edilebilir uyum aralığında olduğu görülmektedir. Lider-üye etkileşimi ve duygusal zekâ ölçeklerinde GFI değerinin kabul edilebilir uyum değer aralığının altında yer almıştır. Shevlin ve Miles (1998) göre GFI değeri örneklem büyüklüğüne ve faktör yüklerine karşı hassasiyet göstermektedir, bu yüzden GFI değerinin tüm analizler için 0,90 alt sınırında aranması mümkün değildir. Analiz sonuçlarında GFI hariç diğer iyilik uyum değerlerinin istenilen aralıkta olmasından dolayı ölçeklerin yeterli uyum gösterdiği kabul edilmiştir. Ayrıca $\mathrm{p}$ anlamlılık $\mathrm{p}<0,01$ olduğu ve ifadelere ilişkin $\mathrm{t}$ değerlerinin 2,56’yı aştığı izlenmektedir. Bu sonuç ölçeklerin istatistiksel olarak anlamlı olduğunu kanıtlamaktadır.

Korelasyon analiziyle birlikte ölçeklere ilişkin ortalamalar, standart sapmalar ve korelasyon değerleri hesaplanmıştır. Tablo 3'te ayrıntılı olarak verilmektedir. 
Tablo 3

Ölçeklerin Ortalama, Standart Sapma ve Korelasyon Değerleri

\begin{tabular}{llcrcccc}
\hline & Değişkenler & Ort. & $\begin{array}{c}\text { Std. } \\
\text { Sapma }\end{array}$ & 1 & 2 & 3 & 4 \\
\hline 1 & Etik Liderlik & 3,7749 &, 61196 & 1 & & & \\
\hline 2 & Lider-Üye Etkileşimi & 3,8511 &, 61561 &, $378^{* *}$ & 1 & & \\
\hline 3 & Duygusal Zekâ & 3,8930 &, 53233 &, $388^{* *}$ &, $367^{* *}$ & 1 & \\
\hline 4 & Yenilikçi Davranış & 3,8452 &, 49723 &, $501^{* *}$ &, $613^{* *}$ &, $814^{* *}$ & 1 \\
\hline$* *$ Korelasyon $p<0,01$ düzeyinde anlamlıdır. & & & & &
\end{tabular}

Tablo 3'te yer alan bulgulara göre ölçeklerin ortalamalarının yüksek olduğu ve her bir değişken arasında pozitif yönlü anlamlı ilişkinin olduğu görülmektedir. Özellikle bağımlı değişken olan yenilikçi davranış ile etik liderlik ve lider-üye etkileşimi arasında orta düzey, duygusal zekâ arasında yüksek düzeyde pozitif yönlü ilişkinin olduğu tespit edilmiştir.

\section{Araştırma Hipotezlerin Test Edilmesi}

Korelasyon analizi ile etik liderlik, lider-üye etkileşimi, duygusal zekâ ve yenilikçi davranış arasında varlığı tespit edilen ilişki, doğrusal regresyon analizi ile etik liderliğin lider-üye etkileşimine ve yenilikçi davranışına olan etkinin, lider-üye etkileşiminin de aynı şekilde yenilikçi davranışa olan etkinin şiddeti ve yönü ölçülmüştür. Ayrıca bağımlı ve bağımsız değişken arasında lider-üye etkileşiminin aracı rolünü tespit etmek için Process Macro Model-4 uygulanmıştır. Analiz sonuçları Tablo 4'te ayrıntılı olarak verilmektedir.

Tablo 4

Regresyon Analizi ve Aracı Etki Sonuçları

$\begin{array}{llllll}\text { Hipotezler } & R^{2} & \text { Standardize } \beta & \text { Std. Hata } & t & p\end{array}$

\begin{tabular}{|c|c|c|c|c|c|c|c|}
\hline H1 & a & Etik Liderlik ---> Lider-Üye Etkileşimi & 0,143 & 0,378 & 0,061 & 6,276 & 0,000 \\
\hline $\mathrm{H} 2$ & $\mathrm{~b}$ & Lider Üye Etkileşimi ---> Yenilikçi Davranış & 0,370 & 0,608 & 0,041 & 11,79 & 0,000 \\
\hline H3 & $\mathrm{c}$ & Etik Liderlik ---> Yenilikçi Davranış & 0,257 & 0,507 & 0,045 & 9,047 & 0,000 \\
\hline $\mathrm{H} 4$ & $\mathrm{c}^{\prime}$ & Etik Liderlik ---> Lider Üye Etkileşimi ---> & 0,459 & 0,314 & 0,042 & 6,252 & 0,000 \\
\hline H5 & & Duygusal Zekâ ---> Yenilikçi Davranış & 0,663 & 0,814 & 0,035 & 21,583 & 0,000 \\
\hline \multicolumn{8}{|c|}{ Dolaylı Etki: Yeniden Örnekleme (Bootstrap) Sonuçları } \\
\hline & & & & Standardize $\beta$ & Std. Hata & $\begin{array}{l}\text { Alt sinır } \\
\% 95 \\
\text { Güven } \\
\text { Aralığ } 1\end{array}$ & $\begin{array}{c}\text { Üst sinır } \\
\% 95 \\
\text { Güven } \\
\text { Aralığ1 }\end{array}$ \\
\hline & & a ve b yolu & & 0,183 & 0,052 & 0,0830 & 0,2844 \\
\hline \multicolumn{8}{|c|}{ Dolaylı Etki: Sobel Testi Sonuçları } \\
\hline & & & & Standardize $\beta$ & Std. Hata & $z$ & $p$ \\
\hline & & a ve b yolu & & 0,187 & 0,029 & 5.2094 & 0,000 \\
\hline
\end{tabular}

Regresyon analizi sonucuna göre; etik liderlikteki artışın lider-üye etkileşimi üzerinde $p<0,01$ anlamlılık düzeyinde 0,378 birimlik artışa yol açtığ $(t=6,276)$, lider-üye etkileşimindeki artışın yenilikçi davranış üzerinde $p<0,01$ anlamlılık düzeyinde 0,608 birimlik artışa yol açtığ $(t=11,790)$, etik liderlikteki artışın yenilikçi davranış üzerinde $p<0,01$ anlamlılık düzeyinde 0,507 birimlik artışa yol açtığı $(t=9,047)$, duygusal zekâdaki artışın yenilikçi davranış üzerinde $p<0,01$ anlamlılık düzeyinde 0,814 birimlik artışa yol açtığı $(t=21,583)$ olduğu tespit edilmiştir. Regresyon yollarına ilişkin $t$ değerlerinin 2,56'nın üzerinde olması, $\beta$ değerlerinin pozitif olması ve $p$ anlamlılık değerinin 
$p<0,01$ düzeyinde olması değişkenler arasında pozitif yönlü anlamlı bir ilişkinin olduğunu göstermektedir. Elde edilen bu sonuçlara göre $\mathrm{H}_{1}, \mathrm{H}_{2}, \mathrm{H}_{3}$ ve $\mathrm{H}_{5}$ hipotezleri kabul edilmiştir.

Lider-üye etkileşiminin aracı etkisini ölçmek için Preacher ve Hayes (2004) tarafından geliştirilen yeniden örnekleme (Bootstrap) ve Baron ve Kenny (1986) tarafından geliştirilen ve üç aşamadan oluşan regresyon analizi birlikte kullanılmıştır. İlk olarak etik liderliğin lider-üye etkileşimine olan etkisi analiz edilmiş (a) $\beta=0,378(p<0,01)$ pozitif yönlü anlamlı ilişkinin olduğu görülmektedir. Sonrasında lider-üye etkileşiminin yenilikçi davranışa olan etkisi (b) $\beta=0,608(p<0,01)$ ve etik liderliğin yenilikçi davranışa olan etkisi (c) $\beta=0,507 \quad(p<0,01)$ analiz edilmiş pozitif yönlü anlamlı ilişkinin olduğu tespit edilmiştir. Lider-üye etkileşimin regresyon analizine dâhil edilmesiyle etik liderliğin yenilikçi davranışa olan etkisi $\left(\mathrm{c}^{\prime}\right) \beta=0,314$ 'e $(p<0,01)$ gerilemiştir. Bu azalma kısmi aracılığın olduğunu göstermektedir. Elde edilen kısmi aracılığın anlamlı olup olmadığını tespit etmek için Jose (2013a) tarafından geliştirilen MedGraph-I programı kullanılarak Sobel testi uygulanmış ve $z=5,20(p<0,01)$ değerinin anlamlılığı olduğu sonucuna ulaşılmıştır. Diğer yöntem olan Process Macro (Model-4) regresyon analizinin sonucunda dolaylı etkinin (ab) $\beta=0,183$ olduğu ve alt ve üst güven aralığının 0,083-0,284 olduğu sonucuna ulaşılmıştır. Preacher ve Hayes (2004) göre yeniden örnekleme (Bootstrap) yönteminde elde edilen alt ve üst güven aralığı sıfır içermemesi gerekmektedir. Yani alt ve üst güven aralığı değerlerinin her ikisi de ya pozitif ya da negatif olması gerekir. Bu sonuca göre de lider-üye etkileşiminin kısmi aracılık etkisinin anlamlı olduğu sonucuna ulaşılmış ve $\mathrm{H}_{4}$ hipotezleri kabul edilmiştir.

Lider-üye etkileşiminin yenilikçi davranış üzerindeki etkisinde duygusal zekânın düzenleyici rolünü belirlemek için Hayes'in (2013) tarafından geliştirilen Process Makro uzantısı (Model-1) kullanılarak regresyon analiz yapılmıştır. Analize ilişkin sonuçlar Tablo 5'te verilmektedir.

Tablo 5

Lider-Üye Etkileşiminin Yenilikçi Davranış Üzerindeki Etkisinde Duygusal Zekânın Düzenleyici Rolü

\begin{tabular}{|c|c|c|c|c|c|c|}
\hline Değişkenler & $\beta$ & Std. Hata & $\mathrm{t}$ & $\mathrm{p}$ & $\begin{array}{l}\text { Alt sınır } \\
\% 95 \\
\text { Güven } \\
\text { Aralığ1 }\end{array}$ & $\begin{array}{l}\text { Üst sinır } \\
\% 95 \\
\text { Güven } \\
\text { Aralığ1 }\end{array}$ \\
\hline Sabit & $-1,019$ & 0,396 & $-2,575$ & 0,010 & $-1,798$ & $-0,239$ \\
\hline Lider Üye Etkileşimi & 0,644 & 0,108 & 5,970 & 0,000 & 0,432 & 0,8566 \\
\hline Duygusal Zekâ & 0,997 & 0,112 & 8,924 & 0,000 & 0,777 & 1,216 \\
\hline $\begin{array}{l}\text { Lider Üye Etkileşimi x Duygusal } \\
\text { Zekâ }\end{array}$ & $-0,099$ & 0,030 & $-3,353$ & 0,001 & $-0,157$ & $-0,041$ \\
\hline \multicolumn{7}{|c|}{ Duygusal Zekânın Düzenleyici Etki Seviyesi } \\
\hline Düşük & 0,311 & 0,027 & 11,658 & 0,000 & 0,259 & 0,364 \\
\hline Yüksek & 0,206 & 0,037 & 5,594 & 0,000 & 0,134 & 0,279 \\
\hline \multirow[t]{2}{*}{ Model Özeti } & $\mathrm{R}$ & $\mathrm{R}^{2}$ & $\mathrm{~F}$ & $\mathrm{p}$ & & \\
\hline & 0,8871 & 0,7869 & 289,264 & 0,000 & & \\
\hline \multirow[t]{2}{*}{ Etkileşim neticesinde artan $\mathrm{R}^{2}$} & $\Delta \mathrm{R}^{2}$ & $\mathrm{~F}$ & $\mathrm{Sd}$ & $\mathrm{p}$ & & \\
\hline & 0,010 & 11,244 & 235 & 0,001 & & \\
\hline
\end{tabular}

Tablo 5'te görüldüğü üzere; lider-üye etkileşimi $x$ duygusal zekâ etkileşim değeri $\beta=-0,099$; $p<0,01$ anlamlı olduğu görülmektedir. Moderatör etkiye yönelik elde edilen modelin özet değerleri $R^{2}=0,7869 ; F=289 ; p<0,01$ anlamlı olduğu görülmektedir. Lider-üye etkileşiminin yenilikçi davranış1 açıklama oranı \% 37'den (Bkz. Tablo 5) \% 78,69'a yükselmiştir. Etkileşim neticesinde artan $R^{2}$ değeri $p<0,01$ anlamlılık düzeyinde $\% 1$ artmış olduğu sonucuna ulaşılmıştır. Elde edilen bu sonuç, lider-üye etkileşiminin yenilikçi davranış üzerindeki etkisinde duygusal zekânın düzenleyici rolünün olduğu sonucuna ulaşılmıştır. Bu duruma göre $\mathrm{H}_{6}$ hipotezi kabul edilmiştir.

Duygusal zekânın farklı düzeylerdeki düzenleyici etkisinin anlaşılması için, Jose (2013b) tarafından geliştirilen ModGraph-I programı kullanılarak çizilen, Grafik 1'de duygusal zekânın düşük 
ve yüksek değere sahip olduğu durumlarda düzenleyici etkileri verilmiştir. Duygusal zekâ düşük seviyede olduğunda $p<0,01$ anlamlıl1k düzeyinde $\beta=0,311 \quad(t=11,658)$, yüksek seviyede olduğunda ise $p<0,01$ anlamlılık düzeyinde $\beta=0,206 ;(t=5,594)$ gerçekleşmektedir. Bu değerler duygusal zekânın artması durumunda, düzenleyici etkinin de azalarak artmaya devam ettiğini göstermektedir.

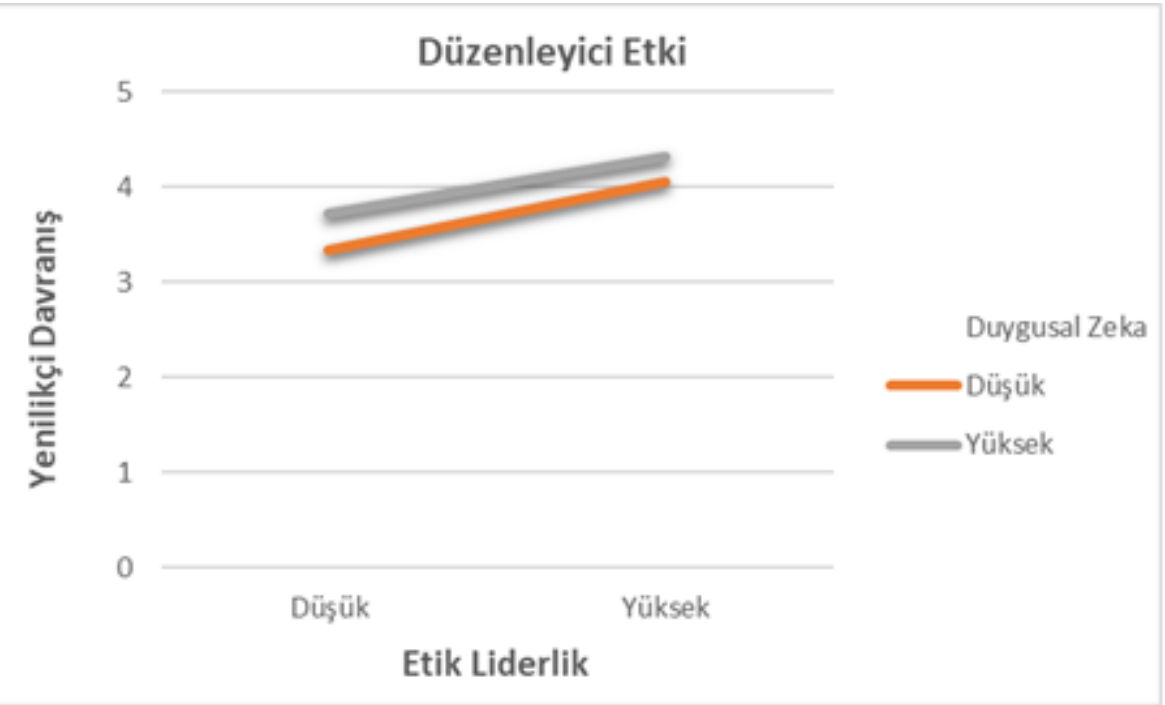

Grafik 1. Farklı Duygusal Zekâ Düzeylerinde Lider-Üye Etkileşimi ve Yenilikçi Davranış İlişkisi

Etik liderlik ile yenilikçi davranış arasındaki ilişkiye aracılık eden lider-üye etkileşimi ve aracı etkiye moderatörlük eden duygusal zekâ değişkenlerinin aynı anda analize eklenmesi sonucu düzenleyici aracılık modeline ilişkin değerler Tablo 6'da verilmektedir.

Tablo 6

Duygusal Zekâ Faktörünün Modele Dâhil Edilmesiyle Oluşan Düzenleyici Aracılık Etki Değerleri

\begin{tabular}{|c|c|c|c|c|c|c|}
\hline \multicolumn{7}{|c|}{ Direkt Etki } \\
\hline & $\beta$ & Std. Hata & $\mathrm{t}$ & $\mathrm{p}$ & $\begin{array}{l}\text { Alt sınır } \\
\% 95 \\
\text { Güven } \\
\text { Aralığ } 1\end{array}$ & $\begin{array}{c}\text { Üst sınır \% } \\
95 \text { Güven } \\
\text { Aralığ1 }\end{array}$ \\
\hline Etik Liderlik --> Yenilikçi Davranış & 0,093 & 0,027 & 3,439 & 0,007 & 0,040 & 0,147 \\
\hline \multicolumn{7}{|c|}{ Düşük ve Yüksek Dolaylı Etki Değerleri } \\
\hline & $\beta$ & Std. Hata & $\begin{array}{l}\text { Alt s1nır } \\
\% 95 \\
\text { Güven } \\
\text { Aralığ1 }\end{array}$ & $\begin{array}{c}\text { Üst sınır \% } \\
95 \text { Güven } \\
\text { Aralığ1 }\end{array}$ & & \\
\hline Düşük & 0,108 & 0,031 & 0,048 & 0,169 & & \\
\hline Yüksek & 0,073 & 0,022 & 0,032 & 0,115 & & \\
\hline \multicolumn{7}{|c|}{ Ilımlı Aracılık Modeli } \\
\hline Model Özeti & İndeks & Std. Hata & $\begin{array}{l}\text { Alt sinır } \\
\% 95 \\
\text { Güven } \\
\text { Aralığ1 }\end{array}$ & $\begin{array}{c}\text { Üst sınır \% } \\
95 \text { Güven } \\
\text { Aralığı }\end{array}$ & & \\
\hline & $-0,033$ & 0,017 & $-0,071$ & $-0,003$ & & \\
\hline
\end{tabular}

Analiz sonucunda elde edilen verilere göre etik liderliğin yenilikçi davranışa olan etkisi (c) $\beta=0,507$ 'den $(p<0,01)$ arac1 ve düzenleyici etki ile birlikte $\left(c^{\prime}\right) \beta=0,093$ 'e $(p<0,01)$ gerilemiştir, bu durum kısmi aracılığın devam ettiğini göstermektedir. Bununla birlikte modele ilişkin yeniden örnekleme (Bootstrap) alt ve üst güven aralığ1 -0,071 ile -0,003 arasında yer alması ve sıfir içermemesi modelin anlamlı olduğunu ortaya koymaktadır. Modelin indeks değerinin -0,033 değeri olması 
duygusal zekânın modele eklenmesiyle lider-üye etkileşiminin aracılık etkisinin zayıfladığı, diğer bir ifadeyle dolaylı etkinin düştüğü görülmektedir. $\mathrm{Bu}$ sonuç göre $\mathrm{H}_{7}$ hipotezi kabul edilmemiştir.

\section{Sonuç, Tartışma ve Öneriler}

$\mathrm{Bu}$ araştırmada etik liderlik, lider-üye etkileşimi ve duygusal zekânın çalışanların yenilikçi davranışlar sergilemesinde etkisi olup olmadığının belirlenmesi ve etik liderlik ile yenilikçi davranış arasındaki ilişkide lider-üye etkileşiminin aracılık rolünün belirlenmesi amaçlanmıştır. Ayrıca, liderüye etkileşiminin aracılık rolünde, duygusal zekânın düzenleyici (moderatör) etkisinin belirlenmesine çalışılmıştır. Etik liderliğin çalışanların yenilikçi davranışları üzerindeki etkisinde, lider-üye etkileşimi ve duygusal zekâ gibi faktörlerin değişkenler arasındaki ilişkiyi güçlendireceği varsayımı ile düzenleyici aracılık modeli geliştirilmiş ve bu kapsamda analizler gerçekleştirilmiştir. Araştırma sonucunda çalışmaya konu olan işletmelerden elde edilen verilere göre:

Etik liderliğin yenilikçi davranış üzerinde pozitif yönlü anlamlı bir etkisinin olduğu belirlenmiştir. Bu sonuca göre; liderlerin çalışanlara karşı etik tutum ve davranışlar içerisinde olması, çalışanların örgüt içerisinde, ekstra rol davranışı olarak, yenilikçi davranışlar sergilemesine yol açmaktadır. Bu durum işletmeleri geleceğe taşıyacağı gibi daha da rekabetçi olmalarını sağlayacaktır. Elde edilen bu sonuçlar, literatürde yer alan (Kalyar vd., 2019; Özsungur, 2019; Tu ve Lu, 2013; Yidong ve Xinxin, 2013; Zehra ve Waheed, 2017) çalışmalarla örtüşmektedir.

Etik liderliğin lider-üye etkileşimi üzerinde pozitif yönlü anlamlı bir etkisinin olduğu belirlenmiştir. $\mathrm{Bu}$ sonuca göre; liderlerin/yöneticilerin örgüt içerisinde daha fazla etik davranışlar sergilemeleri çalışanların onlara güvenmelerine ve aralarındaki etkileşimin daha sağlıklı olmasına yol açmaktadır. Ayrıca bu durum, çalışanların sadakat duygularının artmasına, lider ve işletmenin başarısı için daha fazla çaba sarf etmesine yol açmaktadır. Elde edilen bu sonuçlar, literatürde yer alan (Hassan vd., 2013; Kalyar vd., 2019; Qian vd., 2017; Yuan, Vu, ve Nguyen, 2017; Yuan, Vu, ve Nguyen, 2019) çalışmalarla örtüşmektedir.

Lider-üye etkileşim kalitesinin çalışanların yenilikçi davranışları üzerinde pozitif yönlü anlamlı bir etkisinin olduğu belirlenmiştir. Bu sonuca göre; liderlerin/yöneticilerin, çalışanların örgüt içerisindeki görev ve sorumluklarını yerine getirme performansına bağlı olarak, güven ve eşitlik ilkesine göre çalışanlarını maddi/manevi olarak desteklemelerini, yüksek kalitede etkileşim içerisinde olmalarını çalışanların yenilikçi davranışlar sergilemelerini sağlayacaktır. Elde edilen bu sonuçlar, literatürde yer alan (Atitumpong ve Badir, 2018; Gu vd., 2015; Saeed vd., 2019) çalışmalarla örtüşmektedir.

Duygusal zekânın çalışanların yenilikçi davranışları üzerinde pozitif yönlü anlamlı bir etkisinin olduğu belirlenmiştir. Bu sonuca göre; çalışanlar kendi duygularını ve beraber çalıştığı insanların duygularını anlaması, kendi duygularını kontrol ederek çalışma arkadaşlarıyla yüksek düzeyde iletişim kurmaları güçlü bir motivasyon aracı olarak ortaya çıkmaktadır. Bu motivasyon çalışanların işletmede değişimi arayan, teknolojiyi takip eden, yeni fikirler geliştiren vb. davranışlar sergilemelerine yol açmaktadır. Elde edilen bu sonuçlar, literatürde yer alan (Al-Omari, 2017; Dinçer ve Orhan, 2012) çalışmalarla örtüşmektedir.

Lider-üye etkileşim kalitesinin, etik liderlik ile yenilikçi davranış arasındaki ilişkide kısmi aracılık etkisinin olduğu sonucuna ulaşılmıştır. Bu sonuca göre; liderlerin/yöneticilerin örgüt içerisinde etik davranışlar sergilemeleri çalışanların yenilikçi davranışlar sergilemesi için tek başına yeterli değildir. Etik liderliğin çalışanların yenilikçi davranışlar sergilemesi üzerindeki etkisi, lider ile çalışan arasında yüksek güvene, performans ve ödüle dayalı etkileşim kalitesi üzerinden gerçekleşmektedir. Başka bir ifadeyle etik liderliğin yenilikçi davranış üzerindeki etkisi lider-üye etkileşim kalitesine bağlı olarak gerçekleşmektedir. Elde edilen bu sonuçlar, literatürde yer alan (Dhar, 2016; Kalyar vd., 2019) çalışmalarla örtüşmektedir. 
Lider-üye etkileşiminin yenilikçi davranış üzerindeki etkisinde duygusal zekânın düzenleyici rolünün olduğu belirlenmiştir. Bu sonuca göre; lider-üye etkileşimi ile yenilikçi davranış arasındaki ilişkinin gücü duygusal zekânın düzenleyici etkisiyle birlikte artmaktadır. Çalışanların kendi duygularını ve iş arkadaşlarının duygularını anlaması, bununla birlikte kendi duygularını kontrol edebilmesinin sonucunda, lider-üye etkileşim kalitesinin güçlenmesine ve yenilikçi davranışların ortaya çıkmasındaki etkisinin daha da artmasına yol açmaktadır. Elde edilen bu sonuçlar, literatürde yer alan (Ma ve Chang, 2019) çalışmalarla örtüşmektedir.

Etik liderlik ve yenilikçi davranış arasındaki ilişkide aracılık etkisi olan lider-üye etkileşim kalitesinin, yenilikçi davranışa olan etkisinde duygusal zekânın düzenleyici rolünün olduğu, fakat duygusal zekânın düzenleyici etkisiyle birlikte, lider-üye etkileşim kalitesinin etik liderlik ve yenilikçi davranış arasındaki aracılık etkiyi zayıflattığı belirlenmiştir. Bu sonuç, etik liderlikle yenilikçi davranış arasındaki ilişkide, lider-üye etkileşim kalitesi ve duygusal zekâ gibi değişkenlerin de bağımlı değişken üzerinde bir etkiye sahip olacağını ve bağımsız değişken ile arasındaki ilişkiyi değiştirebileceği anlamına gelmektedir.

$\mathrm{Bu}$ çalışmanın sonuçları, çini/porselen sektöründe çalışanlarının yenilikçi davranışlar sergilemeleri noktasında, etik liderlik davranışı, lider-üye etkileşimi ve duygusal zekânın öncü olduğunu göstermektedir. Diğer bir ifadeyle, çalışanlar etik davranışlar sergileyen, adil, güvenilir, dürüst bir liderlik davranışı karşısında işletmeye katkı sağlamak için daha fazla çaba sarf ettikleri sonucuna ulaşılmıştır. Özellikle çalışanların duygusal olarak zekâ seviyesi arttıkça, çok daha fazla yenilikçi davranışlar sergileme eğilimine girdikleri görülmektedir. İşletmelerin güçlü bir örgüt kültürüne ve memnuniyet düzeyi yüksek çalışanlara sahip olabilmelerinin, ayrıca sürdürülebilir bir başarı yakalayabilmelerinin yolu, örgüt içerisinde etik anlayışın yaygınlaştırılması ve etik kodların anlaşılabilir bir şekilde çalışanlara iletilmesi ile mümkün olabilmektedir. Etik anlayışın yaygınlaştırılması noktasında, çalışanlara rol model olan liderler örgüt için kritik bir öneme sahiptir. Aynı şekilde liderler, çalışanlar ile etkin bir iletişimin kurulması sürecinde de önemli bir rolü vardır. $\mathrm{Bu}$ noktada çalışanların yenilikçi davranışlar gibi ekstra rol davranışları sergilemeleri büyük ölçüde liderlerin/yöneticilerin tutum ve davranışlarına bağlı olarak gelişecektir. Sonuç olarak, işletmelerin sahip olduğu yöneticilerin yetenek ve becerilerini geliştirmesi ve örgüt dışından yüksek nitelikte yöneticilerin işletmeye çekilmesi durumunda, sürdürülebilir bir başarının temelleri atılmış olur.

Bu çalışmada, sınırlı örneklem sayısı ile araştırmanın yapılması çalışma için önemli bir kısıt oluşturmaktadır. Araştırma sonuçlarına yönelik genelleme yapılabilmesi için farklı sektörlerde ve daha geniş örneklem sayısı ile çalışmaların yapılması önerilmektedir. Ayrıca, araştırma sonuçlarının daha anlamlı olması için dönüşümcü, işlemsel, babacan, hizmetkâr vb. liderlik tarzlarını da içeren modellerin geliştirilmesi önerilmektedir.

\section{Kaynaklar}

Al-Omari, M. (2017). Engineers innovative work behavior: The role of emotional intelligence. European Journal of Business and Management, 9(21), 8-18.

Atitumpong, A. and Badir, Y.F. (2018). Leader-member exchange, learning orientation and innovative work behavior. Journal of Workplace Learning, 30(1), 32-47.

Aydın, E. (2017). Kültür bağlamında sosyal mübadele: Kuramsal bir çalışma. Uluslararası İktisadi ve İdari İncelemeler Dergisi, UIK Special Issue, 547-562.

Bal Taştan, S. and Davoudi, S.M.M. (2015). An examination of the relationship between leadermember exchange and innovative work behavior with the moderating role of trust in leader: A study in the turkish context. Social and Behavioral Sciences, 181, 23-32.

Bar-On, R. (2006). The Bar-On model of emotional-social intelligence (ESI). Psicothema, 18(Special Issue), 13-25. 
Baron, R.M. and Kenny, D.A. (1986). The moderator-mediator variable distinction in social psychological research: Conceptual, strategic, and statistical considerations. Journal of Personality and Social Psychology, 51(6), 1173-2001.

Baş, T., Keskin, N. ve Mert, İ. S. (2010). Lider üye etkileşimi (LÜE) modeli ve ölçme aracının Türkçe'de geçerlik ve güvenilirlik analizi. Ege Akademik Bakış Dergisi, 10(3), 1013-1039.

Biçer, C. (2020). Destructive leadership: "Boss from hell”, How not to be one? Ahi Evran Üniversitesi Sosyal Bilimler Enstitüsü Dergisi, 6(1), 295-308.

Brackett, M. A., Mayer, J. D. and Warner, R. M. (2004). Emotional intelligence and its relation to everyday behaviour, Personality and Individual Differences, 36, 1387-1402.

Brown, M. E., Trevino, L. K. and Harrison, D. A. (2005). Ethical leadership: A social learning perspective for construct development and testing. Organizational Behavior and Human Decision Processes, (97), 117-134.

Carmeli, A. (2003). The relationship between emotional intelligence and work attitudes, behavior and outcomes: An examination among senior managers. Journal of Managerial Psychology, 18(8), 788-813.

Chopra, P. K. and Kanji, G. K. (2010). Emotional intelligence: A catalyst for inspirational leadership and management excellence. Total Quality Management, 21(10), 971-1004.

Cropanzano, R. and Mitchell, M. S. (2005). Social exchange theory: An interdisciplinary review. Journal of Management, 31, 874-900.

Çalışkan, A., Akkoç, İ. ve Turunç, Ö. (2019). Yenilikçi davranış: Bir ölçek uyarlama çalışması. Uluslararası İktisadi ve İdari Bilimler Dergisi, 5(1), 94-111.

Dansereau, F., Graen, G.B. and Haga, W. (1975). A vertical dyad linkage approach to leadership in formal organizations. Organizational Behavior and Human Performance, 13, $46-78$.

De Hoogh, A.H. and Den Hartog, D.N. (2008). Ethical and despotic leadership, relationships withleader's social responsibility, top management team effectiveness and subordinates' optimism: A multi-method study. The Leadership Quarterly, 19(3), 297-311.

De Jong, J. P. J. and Den Hartog, D. N. (2007). How leaders influence employees' innovative behavior. Europe Journal of Innovative Management, 10(1), 41-64.

Dhar, R.L. (2016). Ethical leadership and its impact on service innovative behavior: The role of LMX and job autonomy. Tourism Management, 57, 139-148.

Dinçer, H. and Orhan, N. (2012). Relationship between emotional intelligence and innovative work behaviors in Turkish banking sector. International Journal of Finance \& Banking Studies, l(1), 21-28.

Duan, S., Liu, Z. and Che, H. (2018). Mediating influences of ethical leadership on employee creativity. Social Behavior and Personality: An International Journal, 46(2), 323-337.

Düger, Y.S. (2020). Lider-üye etkileşiminin çalışan sesliliği ve işten ayrılma niyeti üzerindeki etkisi: psikolojik güçlendirmenin düzenleyici rolü. Gaziantep University Journal of Social Sciences, 19(3), 1215-1236.

Eisenbei $\beta$, S. A. and Boerner, S. (2013). A double-edged sword: Transformational leadership and individual creativity. British Journal of Management, 24(1), 54-68. 
Goleman, D. (2006), Social intelligence: The new science of social relationships, New York: Bantam Books.

Graen, G.B. and Uhl-Bien, M. (1995). Relationship-based approach to leadership: development of leader-member exchange (LMX) theory of leadership over 25 years: Applying a multi-level multi-domain perspective. The Leadership Quarterly, 6(2), 219-247.

Gu, Q., Tang, T.L-P. and Jiang, W. (2015). Does moral leadership enhance employee creativity? employee identification with leader and leader-member exchange (LMX) in the Chinese context. Journal of Business Ethics, 126, 513-529.

Hassan, S., Mahsud, R., Yukl, G. and Prussia, G.E. (2013). Ethical and empowering leadership and leader effectiveness. Journal of Managerial Psychology, 28(2), 133-146.

Hayes, A. F. (2013). Introduction to mediation, moderation, and conditional process analysis. New York, NY: The Guilford Press.

Hırlak, B., Taşlıyan, M., Fidan, E. ve Gül, H. (2017). Duygusal zekânın iş performansı ve bazı demografik özellikler ile ilişkisi: Kahramanmaraş’ta üretim sektöründe bir uygulama. Kesit Akademi Dergisi, 3(9), 108-130.

Jordan, P.J. and Lawrence, S.A. (2009). Emotional intelligence in teams: Development and initial validation of the workgroup emotional intelligence profile - short version (WEIP-S). Journal of Management and Organization, 15(4), 452-69.

Jordan, P.J. and Troth, A. (2011). Emotional intelligence and leader member exchange. Leadership \& Organization Development Journal, 32(3), 260-280.

Jordan, P.J., Ashkanasy, N.M., Hartel, C.E.J. and Hooper, G.S. (2002). Workgroup emotional intelligence: Scale development and relationship to team process effectiveness and goal focus. Human Resource Management Review, 12(2), 195-214.

Jose, P. E. (2013b). MedGraph-I: A programme to graphically depict mediation among three variables: The internet version, version 3.0. Victoria University of Wellington, Wellington, New Zealand. 01.02.2020 tarihinde https://psychology.victoria.ac.nz/medgraph/ adresinden erişilmiştir.

Jose, P.E. (2013a). ModGraph-I: A programme to compute cell means for the graphical display of moderational analyses: The internet version, Version 3.0. Victoria University of Wellington, Wellington, New Zealand. 02.02.2020 tarihinde https://psychology.victoria.ac.nz/modgraph/ adresinden erişilmiştir.

Kalaycı, Ş. (2016). SPSS uygulamalı çok değişkenli istatistik teknikleri, Ankara: Asil Yayınları.

Kalyar, M., Usta, A. and Shafique, I. (2019). When ethical leadership and LMX are more effective in prompting creativity: The moderating role of psychological capital. Baltic Journal of Management, 15(1), 61-80.

Liao, S.-H., Chen, C.-C. and Hu, D.-C. (2018). The role of knowledge sharing and LMX to enhance employee creativity in theme park work team: a case study of Taiwan. International Journal of Contemporary Hospitality Management, 30(5), 2343-2359.

Liao, S.-S., Hu, D.-C., Chung, Y.-C. and Chen, L.-W. (2017). LMX and employee satisfaction: mediating effect of psychological capital. Leadership \& Organization Development Journal, $38(3), 433-449$. 
Liden, R. and Maslyn, J. (1998). Multidimensionality of leader member exchange: An empirical assessment through scale development. Journal of Management, 24(1), 43-72.

Liden, R.C., Sparrowe, R. T. and Wayne, S. J. (1997). Leader-member exchange theory: The past and potential for the future. Research in Personnel and Human Resources Management, 15, 47119.

Lin, Y. and Wu, J. (2018). A study of the effects of leadership styles on innovation management and organizational innovation in environmental protection industry. Ekoloji, 27(106), 771-777.

Lopes, P.N., Salovey, P. and Straus, R. (2003). Emotional intelligence, personality, and the perceived quality of social relationships. Personality and Individual Differences, 35, 641-58.

Ma, G. and Chang, P-C. (2019). The impact of the leader-member exchange on innovation behavior: psychological empowerment as a mediator and emotional intelligence as a moderator. 4th International Conference on Humanities Science, Management and Education Technology (HSMET July 2019), Advances in Social Science, Education and Humanities Research, 334, 282-288.

Ma, Y., Cheng, W., Ribbens, B.A. and Zhou, J. (2013). Linking ethical leadership to employee creativity: Knowledge sharing and self-efficacy as mediators. Social Behavior and Personality: An International Journal, 41(9), 1409-1419.

Mayer, D. M., Kuenzi, M., Greenbaum, R., Bardes, M., and Salvador, R. B. (2009). How low does ethical leadership flow? Test of a trickle-down model. Organizational Behavior and Human Decision Processes, 108(1), 1-13.

Mayer, J. D. and Salovey, P. (1997). What is emotional intelligence. P. Salovey and D. J. Sluyter (Eds.), Emotional development and emotional intelligence (p. 3-31). New York: Basic Books.

Ordun, G. and Acar, A.B. (2014). Impact of emotional intelligence on the establishment and development of high quality leader member exchange (LMX). Advances in Management and Applied Economics, 4(2), 111-129.

Özsungur, F. (2019). The impact of ethical leadership on service innovation behavior: The mediating role of psychological capital. Asia Pacific Journal of Innovation and Entrepreneurship, 13(1), 73-88.

Preacher, K. J. and Hayes, A. F. (2004). SPSS and SAS procedures for estimating indirect effects in simple mediation models. Behavior Research Methods, 36(4), 717-731.

Qian, J., Wang, B., Han, Z. and Song, B. (2017). Ethical leadership, leader-member exchange and feedback seeking: A double-moderated mediation model of emotional intelligence and workunit structure. Frontiers Psychology, 8(1174), 1-11.

Raghuram, S., Gajendran, R.S., Liu, X. and Somaya, D. (2017). Boundaryless LMX: Examining LMX's impact on external career outcomes and alumni goodwill. Personnel Psychology, 70(2), 399-428.

Rahaman, H.M.S., Stouten, J. and Guo, L. (2019). Antecedents of ethical leadership: The theory of planned behavior. Leadership \& Organization Development Journal, 40(6), 735-746.

Resick, C. J., Hanges, P. J., Dickson, M. W. and Mitchelson, J. K. (2006). A cross-cultural examination of the endorsement of ethical leadership. Journal of Business Ethics, 63, 345-359. 
Saeed, B.B., Afsar, B., Cheema, S. and Javed, F. (2019). Leader-member exchange and innovative work behavior The role of creative process engagement, core self-evaluation, and domain knowledge. European Journal of Innovation Management, 22(1), 105-124.

Salovey, P. and Mayer, J. D. (1990). Emotional intelligence. New York: Baywood Publishing.

Schermuly, C.C., Meyer, B. and Dämmer, L. (2013). Leader-member exchange and innovative behavior the mediating role of psychological empowerment. Journal of Personnel Psychology, 12(3), 132-142.

Scott, S.G. and Bruce, R.A. (1994). Determinants of innovative behavior: A path model of individual innovation in the workplace. Academy of Management Journal, 37(3), 580-607.

Shevlin, M. and Miles, J.N.V. (1998). Effects of sample size, model specification and factor loadings on the GFI in confirmatory factor analysis. Personality and Individual Differences, 25(1), 8590.

Shojaei, M.R. and Siuki, M.E. (2014). A study of relationship between emotional intelligence and innovative work behavior of managers. Management Science Letters, 4, 1449-1454.

Tu, Y. and Lu, X. (2013). How ethical leadership influence employees' innovative work behavior: A perspective of intrinsic motivation. Journal of Business Ethics, 116, 441-455.

Tuna, M., Bircan, H. ve Yeşiltaş, M. (2012). Etik liderlik ölçeğinin geçerlilik ve güvenilirlik çalışması: Antalya örneği. Atatürk Üniversitesi İktisadi ve İdari Bilimler Dergisi, 26(2), 143-155.

Wong, C. S. and Law, K. S. (2002). The effects of leader and follower emotional intelligence on performance and attitude: An exploratory study. Leadership Quarterly, 13, 243-274.

Yidong, T. and Xinxin, L. (2013). How ethical leadership influence employees' innovative work behavior: A perspective of intrinsic motivation. Journal of Business Ethics, 116, 441-455.

Yu, A., Matta, F.K. and Cornfield, B. (2017). Is leader-member exchange differentiation beneficial or detrimental for group effectiveness? A meta-analytic investigation and theoretical integration. Academy of Management Journal, 61(3), 1158-1188.

Yuan, L., Vu, M-C. and Nguyen, T. T. N. (2017). Linking ethical leadership to employee voice behavior: The role of leader-member exchange. International Journal of Business and Management Studies, 7(3), 35-41.

Yuan, L., Vu, M-C and Nguyen, T. T. N. (2019). Effect of ethical leadership and leader-member exchange on voice behavior - moderating impact of empowerment. European Journal of Business and Management, 11(9), 116-123.

Zehra, T.T. and Waheed, A. (2017). Influence of ethical leadership on innovative work behavior: Examination of individual-level psychological mediators. Pakistan Journal of Commerce and Social Sciences, 11(2), 448-470.

Zehra, T.T., Ahmad, H.M. and Waheed, A. (2017). Impact of ethical leadership on innovative work behavior: Mediating role of self-efficacy. Pakistan Journal of Commerce and Social Sciences, 11(2), 448-470.

Zhang, X. and Bartol, K. M. (2010). Linking empowering leadership and employee creativity: The influence of psychological empowerment, intrinsic motivation, and creative process engagement. Academy of Management Journal, 53(1), 107-128.

Zhou, J. (2003). When the presence of creative coworkers is related to creativity: Role of supervisor close monitoring, developmental feedback, and creative personality. Journal of Applied Psychology, 88(3), 413-422. 


\section{Extended Abstract}

\section{Introduction}

The change that took place in the last 20 years in the world has been much faster than previous periods. The innovative behavior of employees at the point of change emerges as the production, promotion, and implementation of new and useful ideas about products, applications, services or procedures. In this context, since ethical leadership addresses values such as morality, justice, autonomy and human orientation within the organization, it is known that it has positive effects on the innovative behavior of employees, especially in terms of morale and motivation. Another leadership approach, Leader-member exchange, gains based on financial or psychological satisfaction offered to the employees cause employees to make extra efforts within the organization. This extra role behavior can exhibition itself as the innovative behavior of employees in organizations. In addition, employees with emotional intelligence will perform well within the organization; that is, it can better define and manage its emotions, understand the feelings of others and respond well. However, it has been revealed in some studies that emotional intelligence plays a key role in employees' innovative behavior.

The purpose of this study is to reveal the effect of ethical leadership on the innovative behavior of employees. Second, to explore the mediating role of leader-member exchange between ethical leadership and employee innovative behavior. Third, to demonstrate the contribution of emotional intelligence to this effect in the effect of leader-member exchange on the innovative behavior of employees. Finally, within the framework of the moderated mediation model developed, the effect of ethical leadership on the innovative behavior of employees will be evaluated from a holistic perspective.

\section{Methodology}

In this research, the easy sampling method adopted. 300 questionnaires were sent to the company's employees operating in the ceramic/porcelain sector in Kütahya and 239 (80\%) available questionnaires were returned. The questionnaires used as data collection method consist of two parts; In the first part, there are 5 expressions to determine the demographic variables, in the second part there are 44 expressions consisting of ethical leadership, innovative behavior, leader-member exchange, and emotional intelligence scale questions and 49 expressions in total. The expressions used in the scales were used in the 5-point Likert type rating ( $1=$ Strongly Disagree - 5=Strongly Agree).

The data obtained from the questionnaires were used for the descriptive and confirmatory factor analysis, correlation analysis, linear regression analysis, moderator (Model-1), mediator (Model 4) and moderated mediation analysis (Model-14). AMOS, SPSS program, and Process Macro (Hayes, 2013) plugins were used within the framework of analysis.

\section{Findings}

According to the result of the regression analysis; an increase in ethical leadership leads to an increase in the leader-member exchange, an increase in leader-member exchange leads to an increase in the innovative behavior level. It was also determined that an increase in ethical leadership leads to an increase in innovative behavior, and an increase in emotional intelligence leads to an increase in innovative behavior. According to these results, $\mathrm{H}_{1}, \mathrm{H}_{2}, \mathrm{H}_{3}$ and $\mathrm{H}_{5}$ hypotheses were accepted.

To measure the mediating effect of leader-member exchange, initially (path a) was analyzed, the effect of ethical leadership on the leader-member exchange was found to be positive and significant. Then, (path b) was analyzed, the effect of leader-member exchange on innovative behavior and (path c) was analyzed, the effect of ethical leadership on innovative behavior. It is concluded that it is positive and significant. The effect of ethical leadership on innovative behavior (path c ') 
decreased when including a leader-member exchange in regression analysis. According to this result, it was concluded that the partial mediating effect of the leader-member exchange was significant and $\mathrm{H}_{4}$ hypotheses were accepted.

According to the results of the analysis; leader-member exchange $\mathrm{x}$ emotional intelligence interaction value is seen to be significant. The summary values of the model obtained for the moderator effect is seen to be significant. This result obtained, it was concluded that emotional intelligence has a moderate role in the effect of leader-member exchange on innovative behavior. According to this result, $\mathrm{H}_{6}$ hypothesis was accepted.

According to the data obtained as a result of the analysis regarding the moderated mediation effect; the effect of ethical leadership on innovative behavior has decreased from (c) $\beta=0,507$ ( $p<0,01)$ to (c ') $\beta=0,093(\mathrm{p}<0,01)$ with the moderated mediation effect, this indicates that partial mediation is continuing. However, the Bootstrap lower and upper confidence are between -0.071 and -0.003 and does not contain zero, which indicates that the model is significant. It is seen that the index value of the model is -0.033 and the emotional intelligence is added to the model, and the mediating effect of the leader-member exchange weakens, in other words, the indirect effect decreases. According to this result, $\mathrm{H}_{7}$ hypothesis was not accepted.

\section{Discussion and Conclusion}

As a result of the research, it has been determined that ethical leadership has a positive and significant effect on innovative behavior. It has been determined that ethical leadership has a positive and significant effect on leader-member exchange. It was determined that the quality of leadermember exchange has a positive and significant effect on the innovative behavior of the employees. It has been determined that emotional intelligence has a positive and significant effect on the innovative behavior of employees. It was concluded that the quality of leader-member exchange has a partial mediating role in the relationship between ethical leadership and innovative behavior. Emotional intelligence has a moderated role in the effect of leader-member exchange on innovative behavior. In the moderated mediation model, in the relationship between ethical leadership and innovative behavior, variables such as leader-member exchange quality and emotional intelligence also have an effect on the dependent variable and can change the relationship between the independent variable. 